\title{
PENGEMBANGAN SISTEM PENDUKUNG KEPUTUSAN UNTUK PENENTUAN PENERIMA BANTUAN RASKIN DENGAN MENGGUNAKAN METODE TOPSIS
}

\author{
Ayunda Prima Dewi ${ }^{1}$, Rudy Ariyanto ${ }^{2}$ \\ Program Studi Teknik Informatika, Jurusan Teknologi Informasi, Politeknik Negeri Malang \\ JL. Soekarno-Hatta No. 9 Malang 65141, Indonesia \\ 1. ayundaprima@gmail.com, ${ }^{2}$ ariyantorudy@gmail.com
}

\begin{abstract}
Abstrak
Salah satu program pemerintah yang diberikan kepada keluarga miskin adalah dengan memberikan raskin. Dalam penentuan calon penerima raskin pemerintah memiliki beragam kriteria supaya pembagian beras tepat sasaran. Namun pada kenyataanya penentuan penerima raskin tidak tertuju pada semua kriteria-kriteria yang ada sehingga hasil penentuan tersebut terkesan bersifat subyektif. Banyaknya warga miskin yang ada di seluruh Indonesia, khususnya Kota Malang dengan beragam kondisi mengakibatkan penentuan calon penerima raskin semakin sulit.

Pada penelitian ini dibuat sebuah Sistem Pendukung Keputusan untuk membantu pihak pengambil keputusan dalam penentuan calon penerima raskin secara cepat dan akurat. Dimana sistem ini nantinya dapat digunakan oleh pemerintah pada Dinas Sosial Kota Malang. Sistem ini menggunakan metode TOPSIS (Technique for Order Performance by Similarity to Ideal Solution). Kelebihan dari TOPSIS antara lain TOPSIS cocok digunakan untuk menyelesaikan suatu masalah dengan beragam kriteria dengan menerapkan bobot nilai pada setiap kriterianya. Perhitungan TOPSIS akan menghasilkan suatu peringkat yang dapat membantu pemerintah dalam membandingkan hasil nilai tiap warga sesuai tingkat kemiskinannya.

Sistem Pendukung Keputusan ini telah diuji dengan membandingkan hasil output sistem dengan perhitungan manual. Berdasarkan hasil tersebut, sistem dapat menentukan kelayakan setiap keluarga dalam menerima raskin dan tingkat keakuratan SPK dalam penelitian ini mencapai 99,99\%.
\end{abstract}

Kata kunci: Sistem Pendukung Keputusan, Raskin, TOPSIS

\section{Pendahuluan}

Banyaknya warga miskin menjadi penyebab utama masalah sosial dan menghambat kemajuan suatu daerah. Sehingga perlunya pemerintah melakukan program penanganan kemiskinan, diantaranya bantuan raskin (beras miskin).

Dalam proses penentuan penerima bantuan raskin jumlah pendaftar program raskin lebih banyak dibandingkan dengan kuota penerima raskin, sehingga diperlukannya proses seleksi oleh Dinas Sosial Kota Malang. Terdapat beberapa permasalahan bahwa distribusi beras tidak jatuh pada pihak yang tepat sehingga menimbulkan rasa ketidakadilan terhadap keluarga miskin lainnya. Hasil yang diharapkan pada proses seleksi tidak sesuai kenyataan karena beragam kriteria yang digunakan dan juga memiliki jangkauan nilai yang berbeda. Pada praktek lapangannya, pengambilan keputusan untuk menentukan penerima beras yang sudah terjadi biasanya tidak mengacu pada kriteria-kriteria yang telah ditentukan sehingga mengakibatkan kecenderungan unsur subyektifitas.

Seiring hal tersebut di atas, bahwa semakin banyak data yang akan diolah dalam proses seleksi penerima bantuan raskin, data yang dihasilkan akan lebih bersifat obyektif dengan membuat suatu aplikasi Sistem Pendukung Keputusan (SPK) untuk dapat membantu pihak terkait Dinas Sosial Kota Malang dalam menentukan keputusannya secara cepat dan akurat.

Sistem Pendukung Keputusan dapat dibuat dengan berbagai metode. Beberapa contoh metode yang digunakan misalnya AHP (Analytic Hierarchy Process). Dalam implementasi menggunakan metode AHP mempunyai kekurangan yaitu orang yang dilibatkan adalah orang yang memiliki banyak pengetahuan yang berhubungan dengan hal yang dipilih dengan metode AHP dan untuk melakukan perbaikan keputusan harus dimulai dari tahap awal. (Saelindri,2014:2). Metode lain yang dapat digunakan yaitu SAW (Simple Additive Weighting). Menurut Ekawati (2013) metode SAW mengharuskan pembuat keputusan menentukan bobot bagi setiap atribut. Skor total untuk sebuah alternatif diperoleh dengan menjumlahkan seluruh hasil perkalian antara rating dan bobot tiap atribut. Selain metode SAW dan AHP terdapat metode lain yang dapat digunakan untuk menyelesaikan masalah dalam 
mengambil keputusan antara lain metode TOPSIS (Technique for Order Performance by Similarity to Ideal Solution). Metode TOPSIS telah digunakan secara luas pada area SPK salah satunya yang akan digunakan adalah untuk penentuan penerima bantuan raskin. Menurut Munandar (2014) kelebihan dari TOPSIS antara lain TOPSIS cocok digunakan untuk menyelesaikan suatu masalah dengan beragam kriteria dengan menerapkan bobot nilai pada setiap kriterianya dan jangkauan nilai yang berbeda. Metode ini menggunakan prinsip bahwa alternatif yang terpilih harus mempunyai jarak terdekat dari solusi ideal positif dan jarak terjauh dari solusi ideal negatif. Pilihan akan diurutkan berdasarkan nilai sehingga alternatif yang memiliki jarak terpendek dengan solusi ideal positif adalah alternatif terbaik. Dengan kata lain alternatif yang memiliki nilai yang lebih besar itulah yang lebih baik untuk dipilih.

\section{Metode TOPSIS}

\subsection{Konsep Dasar}

Technique for Order Performance by Similarity to Ideal Solution (TOPSIS) adalah salah satu metode pengambilan keputusan multikriteria. Metode TOPSIS pertama kali diperkenalkan oleh Yoon dan Hwang (1981). TOPSIS menggunakan prinsip bahwa alternatif yang terpilih harus mempunyai jarak terdekat dari solusi ideal positif dan jarak terpanjang (terjauh) dari solusi ideal negatif untuk menentukan kedekatan relatif dari suatu alternatif dengan solusi optimal.

Solusi ideal positif adalah jumlah dari seluruh nilai terbaik yang dapat dicapai untuk setiap atribut, sedangkan solusi negatif-ideal terdiri dari seluruh nilai terburuk yang dicapai untuk setiap atribut.

\subsection{Kelebihan Metode TOPSIS}

Metode TOPSIS memiliki beberapa kelebihan, yaitu:

-konsepnya sederhana dan mudah dipahami;

-komputasinya efisien; dan

-memiliki kemampuan untuk mengukur kinerja relatif dari alternatif-alternatif keputusan dalam bentuk matematis yang sederhana.

\subsection{Prosedur TOPSIS}

Langkah-langkah penilaian metode TOPSIS: Rangking Tiap Alternatif

Pada penelitian ini calon penerima raskin (warga) diposisikan sebagai suatu alternatif dan disimbolkan dengan A. Sedangkan kriteria penilaian disimbolkan dengan C. TOPSIS membutuhkan ranking kinerja setiap alternatif Ai pada setiap kriteria $\mathrm{Cj}$ yang ternormalisasi yaitu :

$$
r i j=\frac{x i j}{\sqrt{\sum_{i-1}^{m} x_{i j}^{2}}}
$$

dengan $i=1,2, \ldots . m$; dan $j=1,2, \ldots . . n ;(2.1)$

b) Matriks keputusan ternormalisasi terbobot

$$
y_{i j}=w_{i} r_{i j} i
$$$$
\text { dengan } i=1,2, \ldots, m \text { dan } j=1,2, \ldots, n
$$

c) Solusi Ideal Positif Dan Negatif

Solusi ideal positif $\mathrm{A}+$ dan solusi ideal negatif A- dapat ditentukan berdasarkan ranking bobot ternormalisasi (yij) sebagai berikut :

$$
\begin{aligned}
& A^{+}=\left(y_{1}^{+}, y_{2}^{+}, \ldots, y_{n}^{+}\right) ; \\
& A^{-}=\left(y_{1}^{-}, y_{2}^{-}, \ldots, y_{n}^{-}\right) ;
\end{aligned}
$$

dimana:

$y_{j}^{+}$adalah $:-\max y_{i j}$, jika $\mathrm{j}$ adalah atribut keuntungan

$$
:-\min y_{i j} \text {, jika j adalah atribut biaya }
$$

$y_{j}^{-}$adalah : $\min y_{i j}$, jika $\mathrm{j}$ adalah atribut keuntungan : $\max y_{i j}$, jika $\mathrm{j}$ adalah atribut biaya

d) Jarak Dengan Solusi Ideal

Jarak adalah alternatif $\mathrm{A}_{1}$ dengan solusi ideal positif dirumuskan sebagai:

$$
D_{i}^{+}=\sqrt{\sum_{j=1}^{n}\left(y_{i}^{+}-y_{i j}\right)^{2} ; i=1,2, \ldots, m}
$$$$
\mathrm{i}=1,2, \ldots, \mathrm{m}
$$

Jarak adalah alternatif $\mathrm{A}_{1}$ dengan solusi ideal positif dirumuskan sebagai:

$$
\begin{aligned}
& D_{i}^{-}=\sqrt{\sum_{j=1}^{n}\left(y_{i j}-y_{i}^{-}\right)^{2} ; i=1,2, \ldots, m} \\
& \mathrm{i}=1,2, \ldots, \mathrm{m}
\end{aligned}
$$

e) Nilai Preferensi Untuk Setiap Alternatif

Nilai preferensi untuk setiap alternatif (Vi) diberikan sebagai :

$$
V_{i}=\frac{D^{-}}{D^{-}+D^{+}}
$$

Nilai Vi yang lebih besar menunjukkan bahwa alternatif Ai lebih dipilih.

\section{Hasil}

\subsection{Desain Sistem}

\subsubsection{Rancangan Model SPK Raskin}

Komponen sistem pendukung keputusan dapat dilihat pada Gambar 3.1 yaitu subsistem manajemen basis data, subsistem manajemen model, dan subsistem antarmuka pengguna (user interface). 


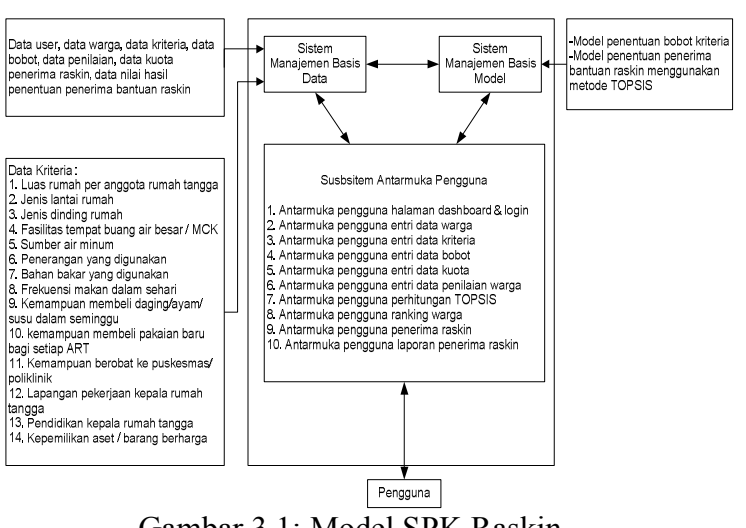

Gambar 3.1: Model SPK Raskin

\subsubsection{Use Case Diagram}

Use case diagram merupakan pemodelan untuk kelakuan (behavior) sistem yang akan dibuat (Rosa A.S., 2013).

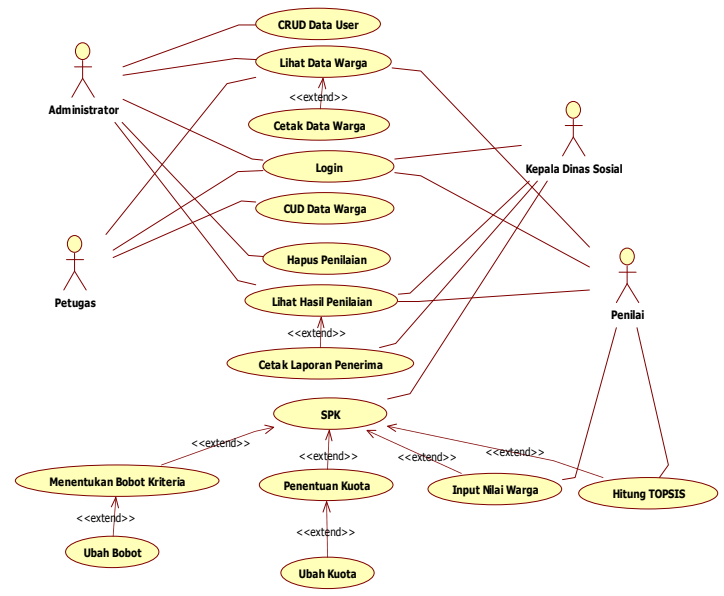

Gambar 3.2: Use Case Diagram

Aplikasi yang akan dibangun adalah Sistem Pendukung Keputusan Untuk Penentuan Penerima Bantuan Raskin. User pada sistem ini ada 4, yaitu:

a) Administrator

Administrator adalah user yang diberikan hak untuk login, mengolah data user yaitu menambah, mengubah, dan menghapus data user. Admin juga dapat melihat data warga, data penerima raskin, data hasil penilaian. Dan melakukan logout.

b) Kepala Dinas

Kepala Dinas merupakan user pengguna yang berperan penting untuk penentuan bobot dan penentuan kuota dalam menjalan spk untuk penentuan penerima bantuan raskin, dan melakukan login pada sistem. Kepala Dinas juga dapat melakukan penilaian, melakukan perhitungan TOPSIS tetapi tanggungjawab ini bersifat opsional karena tugas tersebut dapat sepenuhnya dilakukan oleh penilai.

c) Petugas

Petugas merupakan user pengguna yang menggunakan fasilitas SPK raskin dan telah melakukan login pada sistem. Aktor ini memiliki hak akses petugas yaitu login, isi data warga, lihat data warga, edit data warga, hapus data warga, cetak data warga, dan melakukan logout. Dimana data warga ini yang nantinya digunakan sebagai alternatif yang dipakai dalam perhitungan SPK penentuan penerima bantuan raskin.

d) Penilai

Penilai merupakan user pengguna yang bertugas mengambil keputusan dalam penentuan penerima bantuan raskin, melakukan login pada sistem. Penilai dapat melakukan penilaian, melakukan perhitungan TOPSIS untuk menjalankan SPK penentuan penerima bantuan raskin, melihat hasil penilaian, dan cetak laporan.

\subsubsection{Penentuan Alternatif}

Alternatif yang digunakan dalam sistem ini sebagai calon penerima raskin adalah data sample dari kependudukan Kelurahan Sukun yang termasuk dalam daftar Rumah Tangga Sasaran (RTS) Kota Malang. Kelurahan Sukun dengan luas wilayah 1.055 $\mathrm{km} 2$ dengan jumlah penduduk 20.505 secara administrasi mempunyai 9 RW dan 110 RT. Mempunyai 5.749 KK dengan kepadatan jiwa 19,439 jiwa/km2). Dalam penelitian ini diambil 21 data warga secara acak yang digunakan sebagai data sample.

\subsubsection{Penentuan Kriteria}

Menurut BPS Kota Malang menjelaskan tentang variable non monetary, dimana 14 variabel tersebut nantinya dalam penelitian ini digunakan dalam penentuan penerima subsisdi beras bagi rumah tangga berpendapatan rendah atau raskin.

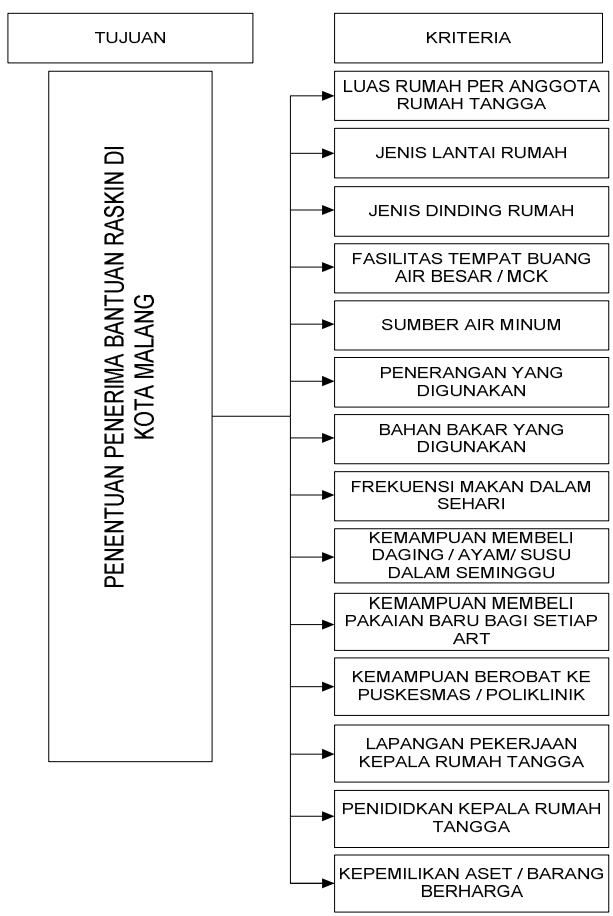

Gambar 3.3: Variable Non Monetary 


\subsubsection{Pembobotan Kriteria}

Pada Sistem Pendukung Keputusan Penentuan Penerima Bantuan Raskin ini prosedur pembobotan ditentukan langsung oleh pengambil keputusan yaitu user Kepala Dinas Sosial dengan jumlah keseluruhan bobot kriteria dalam sistem ini adalah $100 \%$. Semakin besar nilai bobot menunjukkan semakin besarnya tingkat kepentingan kriteria dalam pengambilan keputusan.

\subsubsection{Penentuan Kuota}

Dalam Sistem Pendukung Penentuan Penerima Bantuan Raskin ini untuk menentukan jumlah yang berhak menerima raskin menggunakan prosedur penentuan kuota. Penentuan kuota tersebut ditentukan oleh pengambil keputusan yaitu user Kepala Dinas Sosial sesuai dengan kebijakan yang ada.

\subsubsection{Model Penilaian}

Berikut ini adalah sistem penentuan nilai tiap kriteria (pilihan) berdasarkan kondisi riil calon penerima raskin. Skala penilaian yang digunakan pada kriteria adalah skala 0 sampai 2 dengan keterangan:

- 0 = Tidak Layak Untuk Mendapatkan Raskin

- 1 = Layak Untuk Mendapatkan Raskin

- 2 = Sangat Layak Untuk Mendapatkan Raskin

\subsection{Implementasi}

\subsubsection{Implementasi Basis Data}

Implementasi basis data dilakukan sesuai dengan perancangan yang telah dilakukan. Basis data yang dibuat diberi nama raskin.

Pada basis data raskin terdapat 8 tabel, antara lain user, data_warga, data_anggota_kel, kriteria, bobot, periode, nilai_warga, hasil_akhir.

\subsubsection{Implementasi Program}

Implementasi Sistem Pendukung Keputusan Untuk Penentuan Penerima Bantuan Raskin ini dilakukan dengan bahasa pemrograman PHP. Sedangkan untuk tampilannya menggunakan bootstrap admin template.

- Halaman Login SPK

Gambar 3.3 adalah halaman login. Untuk dapat masuk ke dalam sistem dan menggunakannya user harus mengisi halaman login terlebih dahulu.

User dalam aplikasi ini ada 4, yaitu administrator, kepala dinas sosial, petugas, dan penilai. Masing-masing user akan diarahkan ke halaman yang fungsinya berbeda-beda sesuai dengan tugas masing-masing user sebagaimana dijelaskan pada bagian Use Cae Diagram.

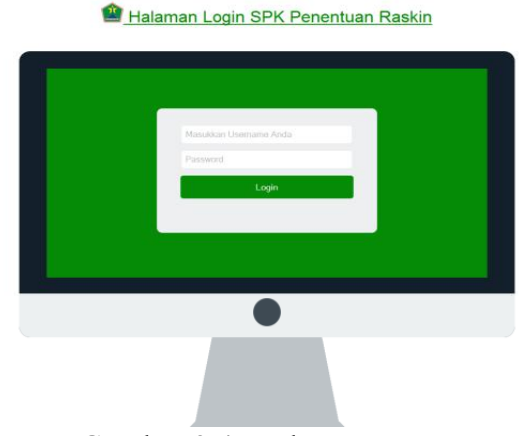

Gambar 3.4: Halaman Login

- Halaman Perhitungan TOPSIS

Pada halaman perhitungan TOPSIS penilai menggunakan metode TOPSIS untuk melakukan seleksi penentuan penerima bantuan raskin. Perhitungan TOPSIS akan membantu pengambil keputusan untuk menentukan penerima raskin secara obyektif. Perhitungan TOPSIS ini dikelola oleh penilai dalam 1 periode saat proses seleksi.

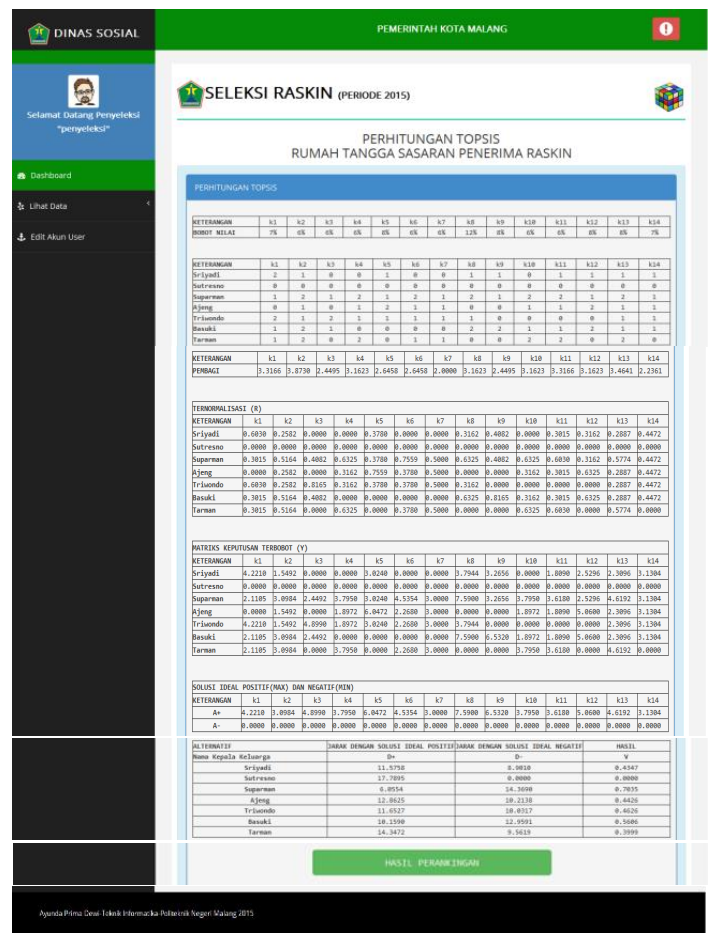

Gambar 3.5: Halaman Perhitungan TOPSIS

\subsection{Pengujian}

\subsubsection{Pengujian Fungsional}

Digunakan untuk menguji fungsi-fungsi khusus dari perangkat lunak yang dirancang. Kebenaran perangkat lunak yang diuji hanya dilihat berdasarkan keluaran yang dihasilkan dari data atau kondisi masukan yang diberikan untuk fungsi yang ada tanpa melihat bagaimana proses untuk mendapatkan keluaran tersebut. Dari keluaran yang dihasilkan, kemampuan program dalam memenuhi kebutuhan pemakai dapat diukur sekaligus dapat diiketahui kesalahan-kesalahannya. Menurut 
pengujian fungsional yang telah dilakukan, hasil yang didapatkan telah berjalan sesuai perencanaan.

\subsubsection{Pengujian Manual}

Tujuan dari pengujian manual adalah menjamin orang yang berinteraksi dengan sistem terotomatisasi dapat melakukan fungsinya secara tepat. Pengujian ini dilakukan dengan cara menghitung ketepatan perhitungan metode dengan bantuan pendukung aplikasi Microsoft Excel. Hasil dari pengujian manual ini akan dicocokan dengan hasil pengujian sistem. Disimpulkan bahwa output dari hasil pengujian manual menunjukkan sistem (nilai TOPSIS) sudah sama dengan hasil perhitungan manual dengan metode TOPSIS.

\subsubsection{Pengujian Sistem}

Pengujian sistem dilakukan dengan menghitung 21 alternatif warga. Jumlah alternatif sama seperti jumlah alternatif pada pengujian manual. Hasil dari pengujian sistem ini didapati telah menunjukkan hasil yang sesuai dengan perhitungan TOPSIS.

\subsubsection{Pengujian Hasil}

\begin{tabular}{|l|r|r|}
\multicolumn{4}{|c}{ Tabel 3.1:Hasil Pengujian } \\
\hline Nama Warga & $\begin{array}{c}\text { Hasil } \\
\text { Pengujian } \\
\text { Manual }\end{array}$ & $\begin{array}{c}\text { Hasil } \\
\text { Pengujian SPK }\end{array}$ \\
\hline Sriyadi & 0,5401 & 0,5401 \\
\hline Kasri & 0,5432 & 0,5432 \\
\hline Suliati & 0,2767 & 0,2767 \\
\hline Sukirman & 0,5104 & 0,5104 \\
\hline Surianto & 0,2679 & 0,2679 \\
\hline Sugito & 0,3367 & 0,3367 \\
\hline Bambang & 0,3242 & 0,3242 \\
\hline Chaterina & 0,3354 & 0,3354 \\
\hline Taslem & 0,2063 & 0,2063 \\
\hline Abdul R. & 0,5364 & 0,5363 \\
\hline Mi Sri & 0,3534 & 0,3534 \\
\hline Baroji & 0,3027 & 0,3027 \\
\hline Wiyono & 0,1618 & 0,1618 \\
\hline Suparto & 0,2332 & 0,2333 \\
\hline Achmad & 0,3227 & 0,3227 \\
\hline Mardiyah & 0,2247 & 0,2247 \\
\hline Lastri & 0,2699 & 0,2699 \\
\hline Samidi & 0,1947 & 0,1947 \\
\hline M.Sapari & 0,2808 & 0,2808 \\
\hline Sutikno & 0,249 & 0,249 \\
\hline Kasiono & 0,3023 & 0,3023 \\
\hline
\end{tabular}

\subsection{Pembahasan}

Dari percobaan pengujian di atas didapatkan kesimpulan bahwa tingkat keberhasilan pembuatan sistem ini telah berhasil dilakukan setelah melakukan implementasi pada sistem pendukung keputusan untuk penentuan penerima raskin dengan menerapkan metode TOPSIS menghasilkan hasil yang sama dengan hasil perhitungan pengujian manual menggunakan metode TOPSIS. Hal ini dibuktikan dengan mengambil jumlah contoh 21 data warga, 19 dari 21 data warga telah menghasilkan hasil keputusan sesuai dengan yang diharapkan. Berikut dibuktikan dalam tabel di bawah ini.

Tabel 3.2:Analisa Pengujian Metode TOPSIS

\begin{tabular}{|l|r|r|r|r|}
\hline \multicolumn{1}{|c|}{$\begin{array}{c}\text { Nama } \\
\text { Warga }\end{array}$} & $\begin{array}{c}\text { Uji } \\
\text { Manual }\end{array}$ & \multicolumn{1}{c|}{$\begin{array}{l}\text { Uji } \\
\text { SPK }\end{array}$} & Error & $\begin{array}{c}\text { Prosentase } \\
\text { Error }\end{array}$ \\
\hline Sriyadi & 0,5401 & 0,5401 & 0,0000 & $0 \%$ \\
\hline Kasri & 0,5432 & 0,5432 & 0.0000 & $0 \%$ \\
\hline Suliati & 0,2767 & 0,2767 & 0,0000 & $0 \%$ \\
\hline Sukirman & 0,5104 & 0,5104 & 0,0000 & $0 \%$ \\
\hline Surianto & 0,2679 & 0,2679 & 0,0000 & $0 \%$ \\
\hline Sugito & 0,3367 & 0,3367 & 0,0000 & $0 \%$ \\
\hline Bambang & 0,3242 & 0,3242 & 0,0000 & $0 \%$ \\
\hline Chaterina & 0,3354 & 0,3354 & 0,0000 & $0 \%$ \\
\hline Taslem & 0,2063 & 0,2063 & 0,0000 & $0 \%$ \\
\hline Abdul R. & 0,5364 & 0,5363 & 0,0001 & $0,0186 \%$ \\
\hline Mi Sri & 0,3534 & 0,3534 & 0,0000 & $0 \%$ \\
\hline Baroji & 0,3027 & 0,3027 & 0,0000 & $0 \%$ \\
\hline Wiyono & 0,1618 & 0,1618 & 0,0000 & $0 \%$ \\
\hline Suparto & 0,2332 & 0,2333 & 0,0001 & $0,0429 \%$ \\
\hline Achmad & 0,3227 & 0,3227 & 0,0000 & $0 \%$ \\
\hline Mardiyah & 0,2247 & 0,2247 & 0,0000 & $0 \%$ \\
\hline Lastri & 0,2699 & 0,2699 & 0,0000 & $0 \%$ \\
\hline Samidi & 0,1947 & 0,1947 & 0,0000 & $0 \%$ \\
\hline M.Sapari & 0,2808 & 0,2808 & 0,0000 & $0 \%$ \\
\hline Sutikno & 0,249 & 0,249 & 0,0000 & $0 \%$ \\
\hline Kasiono & 0,3023 & 0,3023 & 0,0000 & $0 \%$ \\
\hline \multicolumn{7}{|c|}{ Rata-Rata Error } & & $0,0029 \%$ \\
\hline
\end{tabular}

Pada tabel di atas telah dilakukan analisa terhadap pengujian yang dilakukan dengan menggunakan metode TOPSIS. Hasil pengujian awal adalah hasil perhitungan yang dilakukan dengan pengujian manual dan hasil pengujian pada implementasi sistem spk. Sedangkan nilai error merupakan selisih dari hasil pengujian manual dengan hasil pengujian spk. Didapatkan prosentase error yaitu (100\%$0.0029 \%$ ) adalah $99.99 \%$. Berikut perbandingan nilai ditampilkan dalam grafik di bawah ini.

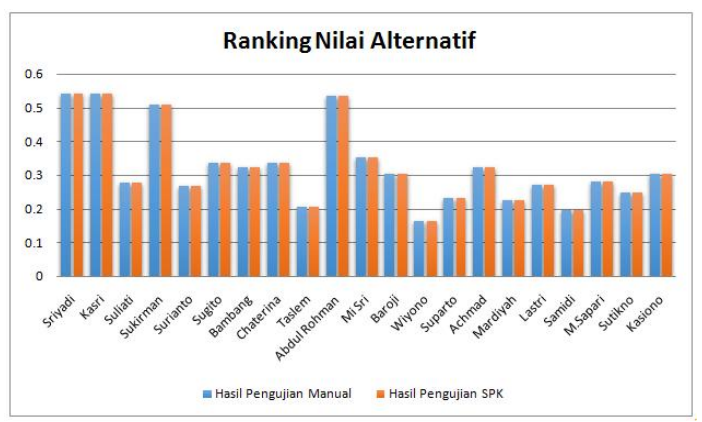

Gambar 3.6: Grafik Ranking Nilai Alternatif

Berikut analisa error 2 data warga dari total 21 data warga yang terdapat pada warga yang bernama Abdul Rohman dan Suparto dengan nilai analisa error 0,0001. Dapat disimpulkan bahwa tingkat keberhasilan hasil spk untuk penentuan penerima raskin pada penelitian ini mencapai 99,99\%. 


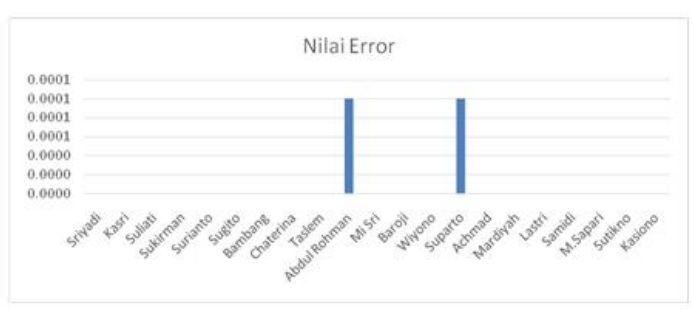

Gambar 3.7: Grafik Analisa Error

\section{Kesimpulan dan Saran}

\subsection{Kesimpulan}

Berdasarkan pembahasan pada bab 1 hingga 6 dapat ditarik beberapa kesimpulan, yaitu: a) Sistem ini telah berhasil menerapkan metode TOPSIS untuk pengambilan keputusan penentuan penerima raskin di Dinas Sosial Kota Malang.

b) Hasil pengujian menunjukkan bahwa perancangan sistem telah menghasilkan sistem yang dapat membantu pengambilan keputusan penentuan penerima raskin secara otomatis dan hasil penilaian menjadi lebih obyektif.

c) Hasil pengujian menunjukkan bahwa performansi sistem ini sudah baik dan menghasilkan hasil yang cukup akurat. Hasil menunjukkan bahwa 19 data warga dari total 21 data warga pada tahap pengujian data manual dibandingkan dengan pengujian menggunakan spk telah mencapai tingkat keberhasilan 99,99\%.

\subsection{Saran}

Sistem pendukung Keputusan dalam penelitian ini masih dibuat dengan sederhana dan bisa dikembangkan menjadi lebih baik.

\section{Daftar Pustaka:}

Ekawati, Aprilia. 2013. Sistem Pendukung Keputusan Pembagian Raskin Dengan Metode Simple Additive Weighting (SAW), Universitas Dian Nuswantoro.

Haryanto, Toto, 2011. Sistem Informasi Pendukung Keputusan, Institut Pertanian Bogor.

Hidayah, Debby Ummul. 2014. Sistem Pendukung Keputusan Menggunakan Metode Analytical Hierarchy Process Dalam Pengolahan Seleksi Perangkat Desa Baru, Sekolah Tinggi Manajemen Informatika dan Komputer Amikom Purwokerto.

Kamus Besar Bahasa Indonesia [Online] Tersedia: http://kbbi.web.id/kuota [waktu akses: 23 Mei 2015, 09:24]

Kusrini, 2007, Konsep dan Aplikasi Sistem Pendukung Keputusan.Yogyakarta: STMIK AMIKOM. [Online] Tersedia:

http://journal.amikom.ac.id/index.php/KIDA/art icle/view/4483 [waktu akses: 08 Februari 2015, 19:28]

Munandar, Tito Aris. 2014. Sistem Pendukung Keputusan Pemilihan Siswa Kelas Unggulan
Pada SMA Negeri 1 Sei Rampah Menggunakan Metode Topsis, STMIK Budidarma Medan.

Pelawi, Dewan. 2011. Sistem Informasi Sebagai Penujang Keputusan Pada UKM PD Gerak Tani Jakarta, Universitas Binus.

Pratama, Devaio. 2015. Sistem Informasi Pendukung Pengambilan Keputusan. [Online] Tersedia: https://www.academia.edu/8570192/MAKALA H_SISTEM_INFORMASI_PENDUKUNG_PE NGAMBILĀN_KEPUTUSANANMata_kuliah_s ystem_informasi_manaje_SISTEM_INFORMA SI_PENDUKUNG_PENGAMBILAN_KEPUT USAN [waktu akses: 11 Januari 2015, 23:58]

Rohayani, Hetty. 2013. Analisis Sistem Pendukung Keputusan Dalam Memilih Program Studi Menggunakan Metode Logika Fuzzy. STIKOM Dinamika Bangsa Jambi

S.A., Rosa, dan Shakahudin. M. 2013. Rekayasa Perangkat Lunak Terstruktur dan Berorientasi Objek. Bandung: Informatika

Saelindri, Pratnya Satria. 2005-2014. Sistem Pendukung Keputusan Untuk Menentukan Kelayakan Penerima Bantuan Siswa Miskin (BSM) Dengan Menggunakan Metode TOPSIS, Jurnal Decision Support Systems, TOPSIS,BSM,MADM, List Of Reference 17(2005-2014)

Setiawan, Galih, dkk. 2011. TOPSIS (Technique For Others Reference by Similarity to Ideal Solution), Universitas Islam Negeri Sunan Kalijaga Yogyakarta.

Website Bulog. [Online] Tersedia: http://www.bulog.co.id/sekilas_raskin.php [waktu akses: 08 Februari 2015, 19:55]

Website Dinas Sosial Kota Malang. [Online] Tersedia: http://dinsos.malangkota.go.id/ [waktu akses : 30 Mei 2015, 23:36]

Website Kelurahan Sukun Kota Malang. [Online] Tersedia:http://kelsukun.malangkota.go.id/profil / [waktu akses: 16 Juni 2015, 02:50]

Website Tim Nasional Percepatan Penanggulangan Kemiskinan. [Online] Tersedia: http://www.tnp2k.go.id/id/tanya-jawab/klasteri/beras-bersubsidi-bagi-masyarakatberpenghasilan-rendah-raskin/ [waktu akses: 11 Januari 2015, 23:45]

Widianto, Bambang. 2013. Program Raskin 2013 Subsidi Beras Bagi Rumah Tangga Berpendapatan Rendah, Kementrian Sekretariat Negara RI Sekeretariat Wakil Presiden. 